\title{
Generation Depth of the Pseudotachylyte from an Out-of-Sequence Thrust in Accretionary Prism- Geothermobarometric Evidence
}

\section{Introduction}

Major out-of-sequence thrusts (OOSTs) in accretionary prisms are faults which generate great earthquakes in subduction zones, such as the 1944 Tonankai and 1946 Nankai earthquakes in the Nankai Trough (Cummins and Kaneda, 2000; Park et al., 2002), the 1964 Alaska earthquake in the Aleutian Trench (Plafker, 1972), and the 2005 Sumatra earthquake in the Sunda Trench (Ammon, 2006). The 1999 Chi-Chi Earthquake in Taiwan along the Chelungpu Fault (Chen et al., 2001) also occurred in the same setting as other OOSTs, even though the fault is exposed on land.

Because great earthquakes of $\mathrm{Mw}>8.0$ dominantly take place in accretive margins (Ruff and Kanamori, 1983), understanding the faulting mechanisms of a major OOST is one of the keys in determining the earthquake generation process as such.

An on-land, fossilized, major OOST thrust exhumed from seismogenic depth can be observed in the early Tertiary Shimanto Belt, Kyushu, Japan (Kondo et al., 2005). The shear zone associated with the thrust is thicker than $100 \mathrm{~m}$ and is characterized by the development of crack-fillings and crack-seal veins, which suggest that the shear zone was filled by geothermal fluids at depth. Velocity analysis of the rocks in the shear zone shows high and low velocities in the hanging wall and footwall, respectively. This is consistent with the impedance contrast expected from negative polarities of the modern out-of-sequence thrust deeper than $10 \mathrm{~km}$ in the Nankai Trough (Tsuji et al., 2006).

A pseudotachylyte-bearing subsidiary fault was recently discovered from the shear zone in the hanging wall (Okamoto et al., 2006). The pseudotachylyte is characterized by ubiquitous association of fluid implosion breccias and mineral veins of quartz and carbonates. This occurrence is very different from that of continental pseu- dotachylytes developed under dry conditions and suggests abundant fluid association, thermal pressurization, and hydrofracturing preceding frictional melting (Okamoto et al., 2006).

It is important to constrain the exact pressure-temperature conditions of the setting for the pseudotachylyte, because its occurrence is a key to understanding the faulting mechanism if the slip took place in depth. From this point of view, we estimated the pressure-temperature conditions on the basis of fluid inclusion analysis from the mineral veins.

\section{Geological Setting of the Nobeoka Thrust}

The Nobeoka thrust is a major OOST bounding the northern and southern Shimanto belts of the CretaceousTertiary accretionary complex in Kyushu, southwest Japan (Fig. 1A). The thrust is traceable for more than $300 \mathrm{~km}$ parallel to the modern Nankai Trough.

Hanging wall rocks of the thrust are composed of the Eocene Kitagawa group mainly consisting of plastically deformed phyllites and sandstones. Footwall strata of the Eocene Hyuga group are composed of a shale matrix mélange with sandstone and basaltic blocks deformed mainly by brittle mechanisms. Deformation fabrics of both of these rocks are consistent with the sense of shear along the Nobeoka thrust (Kondo et al., 2005). Geothermometry using vitrinite reflectance and $\mathrm{CH}_{4}-\mathrm{H}_{2} \mathrm{O}$ fluid inclusion data indicates that the Kitagawa and the Hyuga groups experi-

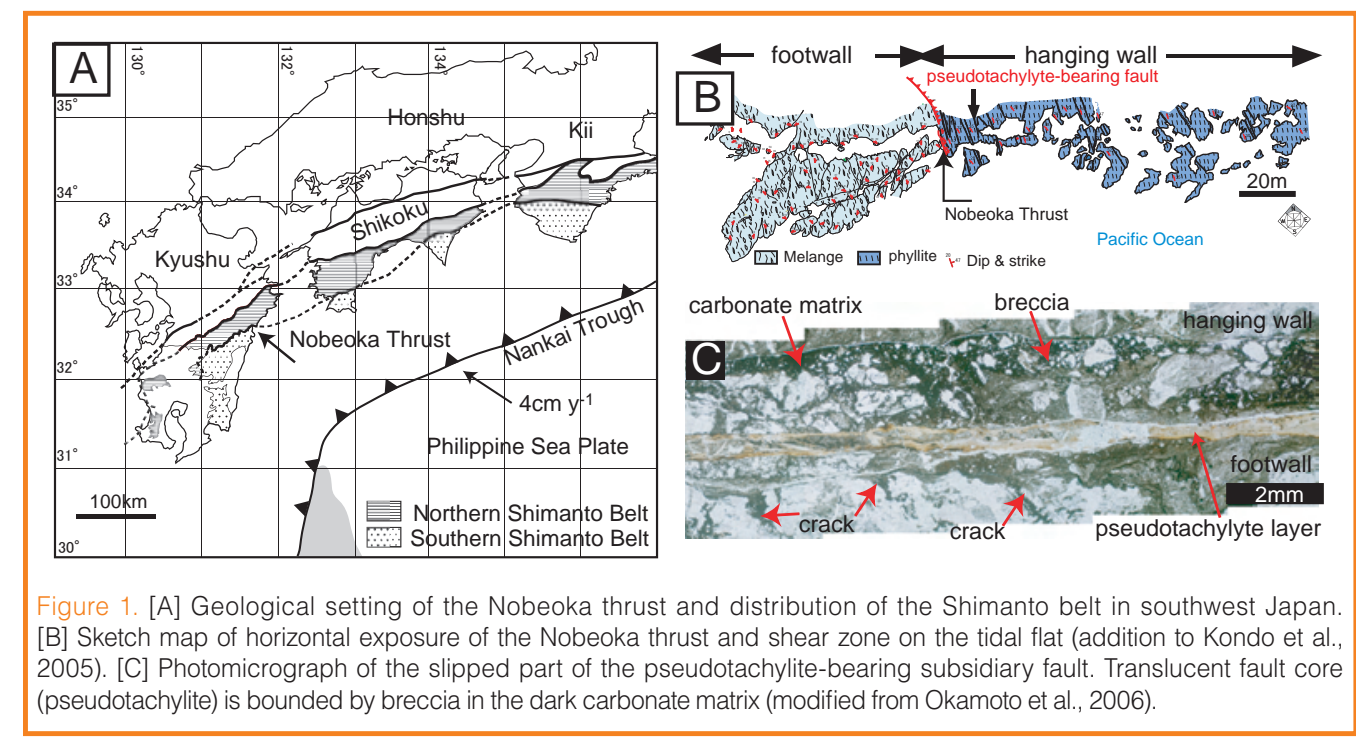


enced heating up to maximum temperatures of $\sim 320^{\circ} \mathrm{C}$ and $\sim 250^{\circ} \mathrm{C}$, respectively (Kondo et al, 2005).

The Nobeoka thrust is characterized by a cataclastic fault core about $20 \mathrm{~cm}$ thick and by a plastic and brittle damage zone whose thickness is several tens of meters in the hanging wall and about 100 meters in the footwall. Ubiquitous subsidiary shear fractures, with orientations parallel to that of the fault core of the Nobeoka thrust, are present in the damaged zones.

Kondo et al. (2005) pointed out from the viewpoint of thermal models (Hyndman and Wang, 1993; Hyndman et al., 1997) that the Nobeoka thrust was formed at seismogenic depths, in comparison with the OOST in the modern Nankai Trough (Park et al., 2002).

Experimentalvelocity measurements of fault rocks from the damaged zone of the Nobeoka thrust show 4-5 $\mathrm{km} \mathrm{s}^{-1}$ for the hanging wall and $3-4 \mathrm{~km} \mathrm{~s}^{-1}$ for the footwall, presenting a clear impedance contrast, and thus a good analog of the deep seismogenic part of a negative polarity of the major OOST in the modern Nankai Trough (Tsuji et al., 2006).

\section{Occurrence of Pseudo- tachylyte and Veins}

A pseudotachylyte-bearing fault was found in one of the subsidiary faults in the hanging wall, about $10 \mathrm{~m}$ above the fault core of the Nobeoka thrust (Fig. 1B; Okamoto et al., 2006). The fault is composed of two different parts along the fault surface: narrow, planar slip sections and wider zones along dilation jogs. The planar slip section shows two types of fault rock. One is a carbonate matrix-supported breccia, and the other is the pseudotachylyte (Fig. 1C). Lines of evidence for frictional melting are discussed by Okamoto et al. (2006). The dilation jogs are filled with carbonate matrix-supported breccia (Okamoto et al., 2006), and the breccias are composed of fragmented host rocks of phyllites several tens of microns to millimeters in size. The carbonate matrix constitutes micron-scale calcite and ankerite, filling the inter-calcite grain boundaries (Fig. 1C).

Crosscutting relationships of veins are as follows (Fig. 2A, B). The oldest veins (V1) occur in the phyllites. Most of them are composed of quartz and are involved in the plastic deformation accommodated by pressure solution (Kondo et al., 2005). Younger quartz veins (V2) are not deformed by such mechanisms, but keep precipitation-related idiomorphic crystal textures. Carbonate veins (V3) fill tension cracks cutting V1 and V2 quartz veins (Fig. 2A, B). The carbonates are connected to the matrix carbonates of the breccias 
(Fig. 2A, B). All vein generations are cut by pseudotachylyte (Fig. 2A, B) in slipped parts of the fault. As described in Okamoto et al. (2006), the pseudotachylyte pinches out at dilation jogs filled by carbonate matrix-supported breccia. These occurrences suggest that the breccia formation and carbonate matrix precipitation were preceded by the frictional melting and maintained during the slip.

\section{Occurrences and Compositions of Fluid Inclusions}

V2 quartz and V3 calcite veins contain abundant fluid inclusions. V2 quartz veins include single-phase and twophase inclusions. The single-phase inclusions are composed only of methane, which is shown by a remarkable peak of $2919.2 \mathrm{~cm}^{-1}$ using Raman micro-spectroscopy. Two-phase inclusions consist of vapor and liquid phases. A broad peak from $3100 \mathrm{~cm}^{-1}$ to $3500 \mathrm{~cm}^{-1}$ indicates water, and a peak of $2917.2 \mathrm{~cm}^{-1}$ coincides with the methane peak. The results suggest that water is saturated with methane, and water and methane co-exist as immiscible fluids (Vrolijk et al., 1988). No solid carbon dioxide was observed during the cooling experiments (see next section), suggesting that carbon dioxide content is less than $10 \%$ (Burruss, 1981).

V3 calcite veins contain only two-phase inclusions. They consist of vapor and liquid phases. Only the water peak from $3100 \mathrm{~cm}^{-1}$ to $3600 \mathrm{~cm}^{-1}$ is detected by Raman microspectroscopy. Therefore, the vapor and liquid phases are both composed of water.

\section{Results of Fluid Inclusion Analysis}

Sixty-eight and sixty-one inclusions, respectively, were analyzed by heating and cooling experiments for V2 quartz veins, while eighty inclusions were analyzed by heating experiments for the V3 calcite veins. Results are shown in Fig. 2C, D, E.

Homogenization temperatures of fluid in V2 quartz veins range from $180^{\circ} \mathrm{C}$ to $296^{\circ} \mathrm{C}$ (Fig. 2C) with a modal peak at $230^{\circ} \mathrm{C}-240^{\circ} \mathrm{C}$. Cooling experiments represent a range from $-130^{\circ} \mathrm{C}$ to $-90^{\circ} \mathrm{C}$ (Fig. 2D). Pressure estimation on the basis of the methane saturation curve (Mullis, 1979) and the results of heating and cooling experiments shows a range of 102-272 MPa. The homogenization temperatures of fluids in the V3 calcite veins were $154^{\circ} \mathrm{C}-362^{\circ} \mathrm{C}$ and present bimodal peaks. The primary peak is at $230^{\circ} \mathrm{C}-260^{\circ} \mathrm{C}$, and the secondary one is at $310^{\circ} \mathrm{C}-320^{\circ} \mathrm{C}$ (Fig. 2E). The primary peak coincides with that of the $\mathrm{V} 2$ quartz veins, and the secondary peak is higher.

\section{Deformation History and its Thermal Conditions}

The crosscutting relationships suggest that the deformation history of the hanging wall was as follows:
1. Ductile deformation related to phyllitic cleavage formation. V1 quartz veins are involved in this deformation. Vitrinite reflectance suggests that the temperature was about $320^{\circ} \mathrm{C}$ (Kondo et al., 2005)

2. Tension cracking and V2 quartz vein precipitation. No more phyllitic cleavages overprint this vein generation, and fluid inclusion analysis suggest that the hanging wall rock was uplifted at about $235^{\circ} \mathrm{C}$.

3. Slip initiation, breccia formation, and carbonate precipitation. These events may have started at about $235^{\circ} \mathrm{C}$, reaching about $320^{\circ} \mathrm{C}$ by frictional heating, and ending with finally cooling to about $235^{\circ} \mathrm{C}$.

4. Continuing slip resulting in frictional melting. Temperatures along the fault may have been more than $1700^{\circ} \mathrm{C}$ locally, as quartz grains show signs of plastic deformation and melting (Okamoto et al., 2006).

\section{Background Geothermal Gradient and Depth at the Initial Stage of Slip}

The paleo-geothermal gradient in the northern Shimanto belt is estimated at $20-30^{\circ} \mathrm{C} \mathrm{km}^{-1}$ based on metamorphic parageneses (Toriumi and Teruya, 1988), while the paleogeothermal gradient in the footwall of the Nobeoka thrust is estimated at $28-47^{\circ} \mathrm{C} \mathrm{km}^{-1}$ based on fluid inclusion analysis (Kondo et al., 2005). However, no studies of the thermal conditions of the hanging wall of the Nobeoka thrust have been reported so far. Here, the geothermal gradient is estimated as follows based on the fluid inclusion analyses described above.

It is assumed that the densest methane fluid inclusions were trapped under nearly lithostatic conditions, because the veins are interpreted to be deposited soon after fracturing under the near-lithostatic fluid pressures (Hashimoto et al., 2003; Matsumura et al., 2003; Vrolijk, 1987). Densities are assumed to be $2700 \mathrm{~kg} \mathrm{~m}^{-3}$ and $1000 \mathrm{~kg} \mathrm{~m}^{-3}$, respectively for solid and fluid.

Thus, fluid pressure $(P)$ is expressed as a function of depth (h) and porosity $(\theta)$ as

$$
P=\int[2700(1-\theta)+1000 \theta] \mathrm{g} d \mathrm{~h}
$$

where $\mathrm{g}$ is the gravity acceleration, $\theta$ is a porosity at depth $\mathrm{h}$ expressed by the empirical equation $\theta=\mathrm{Ae}^{-\mathrm{bh}}$ of Bray and Karig (1985). The equation can be rewritten as

$$
P=\int\left[2700\left(1-\mathrm{Ae}^{-\mathrm{bh}}\right)+1000 \mathrm{Ae}^{-\mathrm{bh}}\right] \mathrm{g} \mathrm{dh}
$$

where $\mathrm{A}$ and $\mathrm{b}$ are constants, 0.65 and 1.54, respectively. The maximum $P$ value of $\mathrm{V} 2$ quartz veins is estimated to be about $240 \mathrm{MPa}$ when a temperature of $235^{\circ} \mathrm{C}$ is assumed. 
Then, solving the equation for $\mathrm{h}$, the depth is calculated as $8.6 \mathrm{~km}$. This yields $27^{\circ} \mathrm{C} \mathrm{km}^{-1}$ of geothermal gradient, which is consistent with previous results from the northern Shimanto belt. Geologic occurrences of the Nobeoka thrust, therefore, present excellent information for faulting mechanisms of seismogenic OOST in depth.

\section{Acknowledgements}

This study was supported by the Research Program for Plate Dynamics of the Japan Agency for Marine-Earth Science \& Technology, and the 21st Century Center of Excellence Program of the University of Tokyo. Our field work was supported by T. Kanda, University of Miyazaki. We are grateful to all the participants of the IODP-ICDP Workshop on Fault Zone Drilling held in Miyazaki for fruitful discussions and comments.

\section{References}

Ammon, C.J., 2006. Megathrust investigations. Nature, 440:31-32, doi:10.1038/440031a.

Bray, C.J. and Karig, D.E., 1985. Porosity of sediments in accretionary prisms and some implications for dewatering processes. J. Geophys. Res., 90:768-778.

Burruss, R.C., 1981. Analysis of fluid inclusions - Phase-equilibria at constant volume. Am. J. Sci., 281:1104-1126.

Chen, Y.-G., Chen, W.-S., Lee, J.-C., Lee, Y.-H., Lee, C.-T., Chang, H.C., and Lo, C.-H., 2001. Surface rupture of 1999 Chi-Chi earthquake yields insights on active tectonics of central Taiwan. Bull. Seismol. Soc. Am., 91:977-985.

Cummins, P.R. and Kaneda, Y., 2000. Possible splay fault slip during the 1946 Nankai earthquake. Geophys. Res. Lett., 27:27252728.

Hashimoto, Y., Enjoji, M., Sakaguchi, A. and Kimura, G., 2003. In situ pressure-temperature conditions of a tectonic melange: Constraints from fluid inclusion analysis of syn-melange veins. Island Arc, 12:357-365, doi:10.1046/j.14401738.2003.00405.x.

Hyndman, R.D. and Wang, K., 1993. Thermal constraints on the zone of major thrust earthquake failure-the Cascadia Subduction Zone. J. Geophys. Res., 98:2039-2060.

Hyndman, R.D., Yamano, M., and Oleskevich, D.A., 1997. The seismogenic zone of subduction thrust faults. Island Arc, 6:244260, doi:10.1111/j.1440-1738.1997.tb00175.x.

Kondo, H., Kimura, G., Masago, H., Ohmori-Ikehara, K., Kitamura, Y., Ikesawa, E., Sakaguchi, A., Yamaguchi, A., and Okamoto, S., 2005. Deformation and fluid flow of a major out-ofsequence thrust located at seismogenic depth in an accretionary complex: Nobeoka Thrust in the Shimanto Belt, Kyushu, Japan. Tectonics, 24:TC6008, doi:10.1029/ 2004 TC001655.

Matsumura, M., Hashimoto, Y., Kimura, G., Ohmori-Ikehara, K., Enjohji, M., and Ikesawa, E., 2003. Depth of oceanic-crust underplating in a subduction zone: Inferences from fluidinclusion analyses of crack-seal veins. Geology, 31:10051008, doi:10.1130/G19885.1.
Mullis, J., 1979. The system methane-water as a geologic thermometer and barometer from the external part of the central Alps, Bull. Mineral., 102:526-536.

Okamoto, S., Kimura, G., Takizawa, S., and Yamaguchi, H., 2006. Earthquake fault rock indicating a coupled lubrication mechanism. e-Earth, 1:23-28.

Park, J.O., Tsuru, T., Kodaira, S., Cummins, R., and Kaneda, Y., 2002. Splay fault branching along the Nankai subduction zone. Science, 297:1157-1160, doi10.1126/science.1074111.

Plafker, G., 1972. Alaskan earthquake of 1964 and Chilean earthquake of 1960 - implications for arc tectonics. J. Geophys. Res., 77:901-925.

Ruff, L. and Kanamori, H., 1983. Seismic coupling and uncoupling at subduction zones. Tectonophysics, 99(2-4):99-117, doi:10.1016/0040-1951(83)90097-5.

Toriumi, M. and Teruya, J., 1988. Tectono-metamorphism of the Shimanto Belt. Mod. Geol., 12:303-324.

Tsuji, T., Kimura, G., Okamoto, S., Kono, F., Mochinaga, H., Saeki, T., and Tokuyama, H., 2006. Modern and ancient seismogenic out-of-sequence thrusts in the Nankai accretionary prism: Comparison of laboratory-derived physical properties and seismic reflection data. Geophys. Res. Lett., 33:L18309, doi:10.1029/2006GL027025.

Vrolijk, P., 1987. Tectonically driven fluid-flow in the Kodiak accretionary complex, Alaska. Geology, 15:466-469.

Vrolijk, P., Myers, G., and Moore, J.C., 1988. Warm fluid migration along tectonic mélanges in the Kodiak accretionary comprex, Alaska. J. Geophys. Res., 93:10313-10324.

\section{Authors}

Shin'ya Okamoto, Department of Earth and Planetary Sciences, Graduate School of Science, The University of Tokyo, 7-3-1 Hongo, Bunkyo-ku, Tokyo, 113-0033, Japan.

Gaku Kimura, Department of Earth and Planetary Sciences, Graduate School of Science, The University of Tokyo, 7-3-1 Hongo, Bunkyo-ku, Tokyo, 113-0033, Japan; and Institute for Research on Earth Evolution (IFREE), Japan Agency for Marine-Earth Science and Technology, 2-15 Natsushimacho, Yokosuka, Kanagawa, 237-0061, Japan, e-mail: gaku@ eps.s.u-tokyo.ac.jp.

Asuka Yamaguchi, Department of Earth and Planetary Sciences, Graduate School of Science, The University of Tokyo, 7-3-1 Hongo, Bunkyo-ku, Tokyo, 113-0033, Japan.

Haruka Yamaguchi, Department of Earth and Planetary Sciences, Graduate School of Science, The University of Tokyo, 7-3-1 Hongo, Bunkyo-ku, Tokyo, 113-0033, Japan; and Institute for Research on Earth Evolution (IFREE), Japan Agency for Marine-Earth Science and Technology, 2-15 Natsushima-cho, Yokosuka, Kanagawa, 237-0061, Japan.

Yoko Kusuba, Department of Earth and Planetary Sciences, Graduate School of Science, The University of Tokyo, 7-3-1 Hongo, Bunkyo-ku, Tokyo, 113-0033, Japan. 